\title{
Protein expression patterns provides clues to tumor formation in familial adenomatous polyposis
}

Christoph Roser

Csaba Tóth

Marcus Renner

Esther Herpel

Peter Schirmacher

\section{Video Byte}

Keywords: Cell Communication and Signaling, apoptosis repressor with caspase recruitment domain, ARC, apoptosis, familial adenomatous polyposis, FAP, Bcl-2, COX-2, p53, $\beta$-catenin, mismatch repair protein, autosomal dominant disease, adenomatous polyposis coli gene, APC, cytoplasm, nucleus, immunohistochemistry, adenoma, polyp, MMR protein

Posted Date: February 26th, 2021

DOI: https://doi.org/10.21203/rs.3.rs-276209/v1

License: (a) (1) This work is licensed under a Creative Commons Attribution 4.0 International License. Read Full License 


\section{Abstract}

Familial adenomatous polyposis (FAP) is an inherited disorder characterized by the formation of up to several thousand tumors in the rectum and colon. FAP is usually caused by a mutation of the adenomatous polyposis coli (APC) gene. While the molecular changes linking this mutation to tumor formation are not fully understood, dysregulated apoptosis-a form of programmed cell death-is known to play a prominent role. Now, researchers have uncovered a pattern of expression of an apoptosisregulating protein that may help explain how FAP tumors form. The protein is called apoptosis repressor with caspase recruitment domain, or ARC. The team examined the expression of ARC in 212 FAP tumor samples from 80 patients. They found that ARC was expressed in the cytoplasm of most tumor cells, as well as in the nuclei. Moreover, nuclear ARC expression positively correlated with overexpression of Bcl-2, COX-2, p53, and $\beta$-Catenin, suggesting that nuclear ARC might play a substantial role not only in carcinomas but also in precursor lesions. Further studies on the intracellular distribution of ARC are now required in order to investigate the different intracellular effects of ARC expression on precursor lesions and lesions with a higher grade of dysplasia. 